\title{
DIFFERENT ANTIMICROBIAL EFFECTS OF RASPBERRY DEPENDING ON THE METHOD OF ACTIVE COMPONENTS ISOLATION
}

\author{
Tamara P. Krstić ${ }^{1}$, Ljiljana Đ. Suvajdžić ${ }^{2}$, Srđan Z. Stojanović ${ }^{1}$, Maja J. Velhner ${ }^{3}$, \\ Dubravka S. Milanov ${ }^{3}$, Gordana M. Bojić ${ }^{4}$, Nebojša M. Ilić ${ }^{5}$ \\ ${ }^{1}$ European University, Faculty of Pharmacy, Trg mladenaca 5, Novi Sad, Serbia \\ ${ }^{2}$ University of Novi Sad, Faculty of Medicine, Department of Pharmacy, Hajduk Veljkova 1, \\ Novi Sad, Serbia \\ ${ }^{3}$ Scientific Veterinary Institute "Novi Sad", Rumenačka 20, Novi Sad, Serbia \\ ${ }^{4}$ Institute of Public Health of Vojvodina, Futoška 121, Novi Sad, Serbia \\ ${ }^{5}$ University of Novi Sad, Institute of Food Technology, Bulevar Cara Lazara 1, Novi Sad, Serbia
}

*Corresponding author:
Phone: +381641526626
E-mail address: giba57@eunet.rs

ABSTRACT: Raspberry fruit exhibits numerous beneficial effects for veterinary and human medicine. One of those effects is antimicrobial activity, because of its diverse chemical composition. Adequate processing of plant material is the most important part of examining their activities. Processing conditions affect the separation of chemical substances in the test sample i.e. different methods can lead to separation of different active principles.

Raspberry juice was produced by filtration. Raspberry pomace, the residue from the pressing of raspberries for juice production was extracted with ethanol and ether. The aim of this study was to determine the most suitable extraction procedure in order to obtain extract with the highest antimicrobial potential. The results of well diffusion method indicate that raspberry juice and ethanol extract of raspberry pomace have shown higher antimicrobial potential in comparison to ether extract.

Keywords: raspberry, antimicrobial, isolation of active principles, juice, ethanol, ether

\section{INTRODUCTION}

Raspberry (Rubus idaeus, (L.), Rosaceae) has rich and diverse chemical composition, in which numerous polar and nonpolar compounds are present. The polar compounds of raspberry are: vitamin C, organic acids ( $2 \%$ citric acid, malic acid and fumaric acid), sugars, pectin, volatile aromatic substances (Tucakov, 1990), phenolic compounds such as phenolic acid (ellagic acid and its derivatives, tannins), flavonoids (flavan-3-ol and its oligomers, quercetin), and anthocyanins (cyanidin-3-soforoside, cyanidin-3-(2-glukosilrutinoside), cyanidin-3-glucoside, pelargonidin-3-soforoside, cyanidin-3-rutinoside, pelargonidin-3-(2-glucosilrutinoside), pelargonidin-3-glucoside, pelargonidin-3- rutinoside) (Mullen et al., 2002; Anttonen et al., 2005; Zhang et al., 2010; Daniel et al., 1989; Hellstrom et al., 2009). As for the nonpolar compounds, raspberry fruit contains significant amount of them, such as essential fatty acids (C18: $2 n-6$ and C18: $3 n-3)$, which exhibit specific biochemical activities (Kafkas et al., 2008).

Due to their frequent application, the resistance to conventional antibiotics is growing among humans', domestic and even wild animals' pathogen microorganisms (Velhner et al., 2012). Plants with antimicrobial activity are a good alternative to conventional antibiotic therapy of infected animals, because they are readily available, harmless to health and have attract- 
tive flavors. Numerous studies have shown antibacterial activity of different parts of raspberry (Krisch et al., 2008; Riaz et al., 2011; Velićanski et al., 2012). The mechanism of raspberries antimicrobial activity has not been completely elucidated. Numerous studies reported antimicrobial potential of anthocyans, ellagotannins and organic acids (Krisch et al., 2009; Puupponen-pimi et al., 2005). Influence of $\mathrm{pH}$ on the raspberry action against microorganisms is also reported (Puupponen-Pimia et al., 2005). However, there is no data on the antimicrobial activity of other compounds present in the raspberry fruits.

In order to examine antimicrobial activity of all substances present in the raspberry fruit, three different extraction procedures were performed: simple filtration, extraction with polar solvent and extraction with nonpolar solvent. The aim of this study was to determine which of these methods of extraction is the most suitable for investtigating antimicrobial activity of raspberries in vitro by well diffusion method.

\section{MATERIALS AND METHODS}

\section{Test material}

Raspberry cultivar Meeker was obtained from the "Elixir" factory (Šabac, Serbia). Freshly harvested fruits were processed the same day. Raspberry juice was produced by filtration through gauze and Buchner funnel into a glass bottle. After squeezing fruits, $200 \mathrm{ml}$ of a mixture containing $80 \%$ of ethanol, $19.95 \%$ water and $0.05 \%$ acetic acid was poured over $200 \mathrm{~g}$ of residue (pomace). The mixture was treated by shaker (KS501, IKA) at $250 \mathrm{rpm}$ at $25^{\circ} \mathrm{C}$ for 30 minutes, and then filtered using filter paper and funnel. The procedure was repeated by adding $100 \mathrm{ml}$ of solvent mixture and treated for 15 minutes. Obtained blends were evaporated to dryness on a rotary vapor (RV10, digital V, IKA). $1 \mathrm{~g}$ of the resulting ethanol extract was dissolved in $15 \mathrm{ml}$ of sterile distilled water. After ethanol extraction, pomace was poured with $100 \mathrm{ml}$ of ether and treated by shaker at $250 \mathrm{rpm}$ at $25{ }^{\circ} \mathrm{C}$ for 15 minutes, and then filtered using funnel and filter paper.

\section{Tested microorganisms}

Sixteen bacterial, fungus and alga strains were used to assess the antimicrobial properties of the test samples (juice of fresh fruits, ethanol and ether extracts of raspberry pomace), including eight Gram positive bacteria (Staphylococcus aureus, Staphylococcus aureus ATCC 11632, Streptococcus agalactiae, Rhodococcus equi, Rhodococcus equi ATCC 6939, Arcanobacterium pyogenes, Arcanobacterium haemolyticum, Enterococcus spp.), six Gram negative bacteria (Pseudomonas aeruginosa, Pseudomonas aeruginosa ATCC 10145, Escherichia coli, Salmonella Enteritidis, Salmonella Typhimurium ATCC 14028, Klebsiella spp,) and one fungus (Candida albicans) and alga (Prototheca wichermanii) strain.

All indigenous isolates tested originated from animals, and reference isolates belong to the ATCC (American Type Culture Collection) strains.

\section{Microbial susceptibility testing}

The microbial susceptibility assay was performed in accordance with the guidelines of the Clinical and Laboratory Standards Institute (CLSI, 2006) using agar well diffusion method. The density of the suspensions of tested microorganisms was adjusted to turbidity equal to the 0.5 MacFarland standard. Wells $(5 \mathrm{~mm}$ in diameter, volume $80 \mu \mathrm{l}$ ) made in agar were filled with a test samples, negative and positive controls. The agar plates were incubated at $37{ }^{\circ} \mathrm{C}$ for 24 hours. Antimicrobial activity of tested samples was determinated by the measurement of the zones of microbial growth inhibition. All tests were performed in triplicates. Distilled water and ether were used as negative controls, whereas streptomycin and nystatin (Galenika, Zemun, Serbia) were used as positive controls. Streptomycin $(2000 \mu \mathrm{g} / \mathrm{ml})$ and nystatin (6-25 $\mu \mathrm{g} / \mathrm{ml}$ ) were dissolved in physiological saline before testing.

Statistical analysis was performed in Microsoft Office Excel 2007 program (Microsoft, One Microsoft Way, Redmond, VA, USA).

\section{RESULTS AND DISCUSSION}

Results are shown in Figures 1-4. 


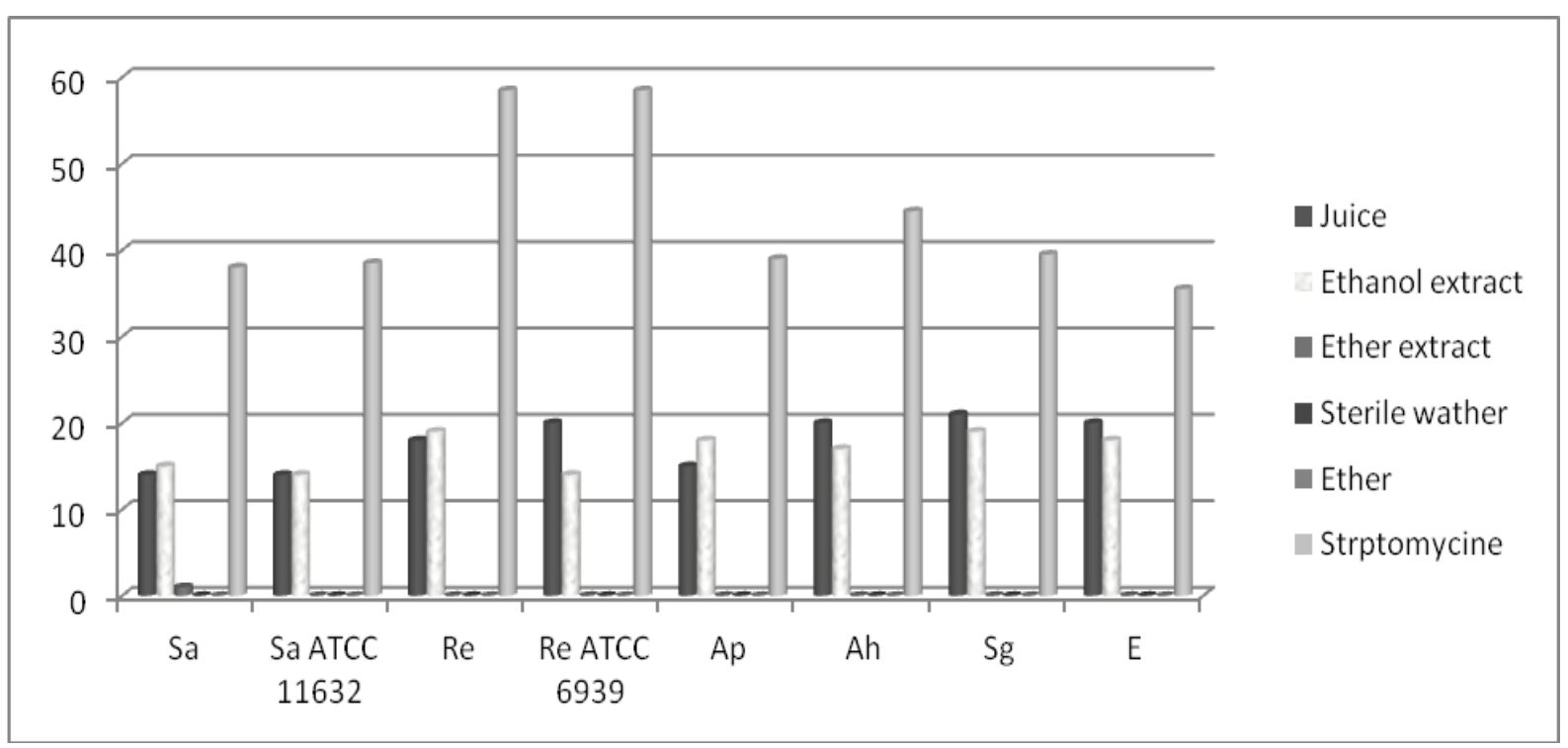

Figure 1. Mean values of inhibition zones' diameters $(\mathrm{mm})$ of test substances against Gram-positive organisms (Sa-S. aureus, Sa ATCC 11632-S. aureus ATCC 11632, Re- $R$. equi, Re ATCC 6939- $R$. equi ATCC 6939, Ap-A. pyogenes, Ah- $A$. haemolyticum, Sg-S. agalactiae, E-Enterococcus spp.)

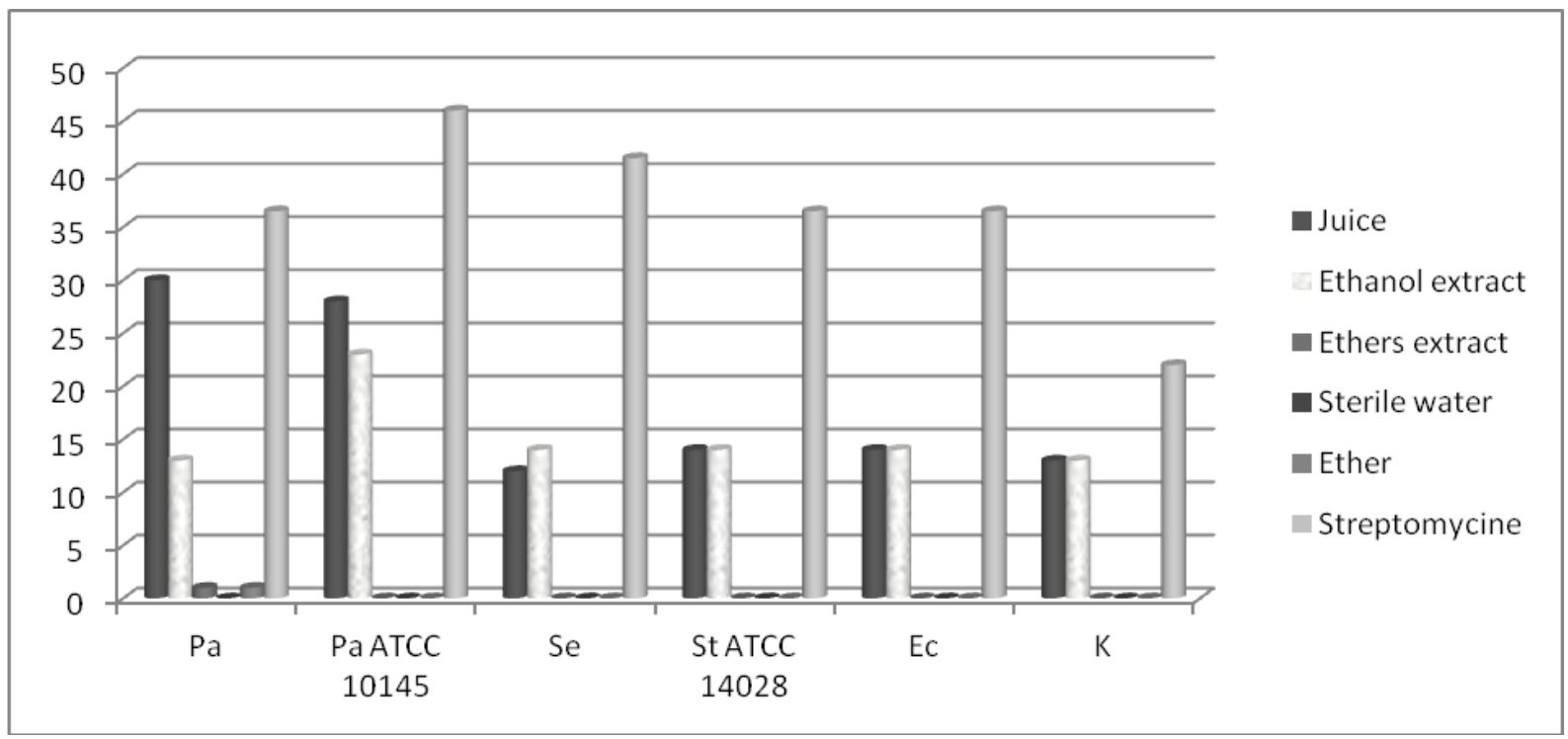

Figure 2. Mean values of inhibition zones' diameters $(\mathrm{mm})$ of the test substances against Gramnegative organisms (Pa-P. aeruginosa, Pa ATCC 10145-P. aeruginosa ATCC 10145, Se-S.

Enteritidis, St ATCC 14028-S. Typhymurium ATCC 14028, Ec-E. coli, K-Klebsiella spp.)

Standard deviations between three examinations were $0.5-1.5 \mathrm{~mm}$. This study has demonstrated good antibacterial activity of the raspberry ethanol extract and juice on Gram positive bacteria. Juice exhibited stronger, statistically relevant $(\mathrm{p}<0.05)$, antibacterial activity on Enterococcus spp., $R$. equi ATCC 6939, A. haemolyticum and $S$. agalactiae. Equal action was expressed on $S$. aureus ATCC 11632. Statistically significant $(p>0.05)$ stronger action of ethanol extract was ex- hibited on $S$. aureus, $R$. equi and $A$. pyogenes (Fig. 1).

Velićanski et al. (2012) also tested the antimicrobial activity of raspberry (cultivar Meeker) fruit and pomace extracts (concentration of $50 \mathrm{mg} / \mathrm{ml}$ ) against Gram positive and Gram negative bacteria using well diffusion method. The strongest antibacterial activity of pomace extracts was observed against S. aureus ATCC 11632 (inhibition zones of 41.5 and $48.5 \mathrm{~mm}$ ). 
For other investigated isolates we have not found comparable data in the available literature.

Juice exhibited statistically significant $(p<0.05)$ stronger antibacterial activity on $P$. aeruginosa indigenous $(30 / 13 \mathrm{~mm})$ and ATCC $(28 / 23 \mathrm{~mm})$ species than ethanol extract. Regarding the antimicrobial activity against $S$. Enteritidis, $S$. Typhymurium ATCC 14028, E. coli and Klebsiella spp. raspberry juice and ethanol extract showed similar potential (Fig. 2).

Similar results were obtained by Velićanski et al. (2012) with slightly different experimental technique. Activity of methanol extracts against $P$. aeruginosa indigenous isolate was stronger in comparison to our ethanol extract but lower than our juice activity. According to the study of Velićanski et al. (2012) the strongest activity of the tested extract was obtained against $E$. coli ATCC 10536 while ethanolic pomace extract used in this study have shown significantly lower activity against this microorganism.

Regarding the activity against $S$. Typhymurium ATCC 14028 significant differences in these two studies were obtained. Different antimicrobial potential of methanol and ethanol extracts of the same raspberry specie could be explained by dif- ferences in: the chemical composition of extracts, geographic origin of raspberry, time of harvest, method of storage and extraction.

Krisch et al. (2008) also examined the effects of juice, water and methanol extracts of raspberry and other plants against Gram-positive and Gram-negative bacteria. Activity of these extracts against $E$. coli decreased in the following order: juice $>$ methanol $>$ water.

Krisch et al. (2009) investigated antimicrobial activity of water and methanol extracts of various fruits' pomaces (including raspberries) using dilution method. Moderate activity of methanol extract was obtained against E. coli and S. Typhymurium. In our study ethanol extract showed moderate activity against these two microorganisms.

Moderate antifungal activity against $C$. albicans was obtained only for raspberry juice with mean inhibition zones of $12 \mathrm{~mm}$ (Fig. 3).

Krisch et al. (2009) investigated raspberry methanol extracts against $C$. albicans and these authors reported poor inhibitory effect (less than 25\%) against this microorganism which is comparable with our results for ethanol extract which did not shown any antifungal activity.

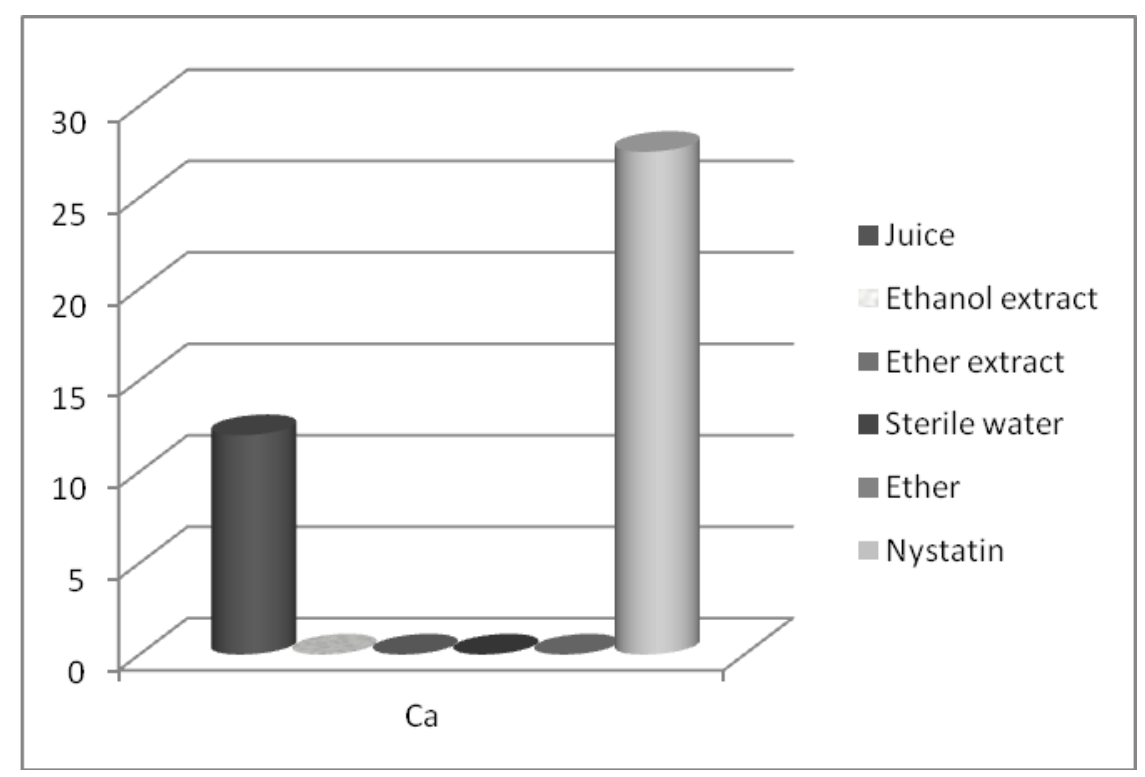

Figure 3. Mean values of inhibition zones' diameters $(\mathrm{mm})$ of the test substances against the fungus (Ca-Candida albicans) 


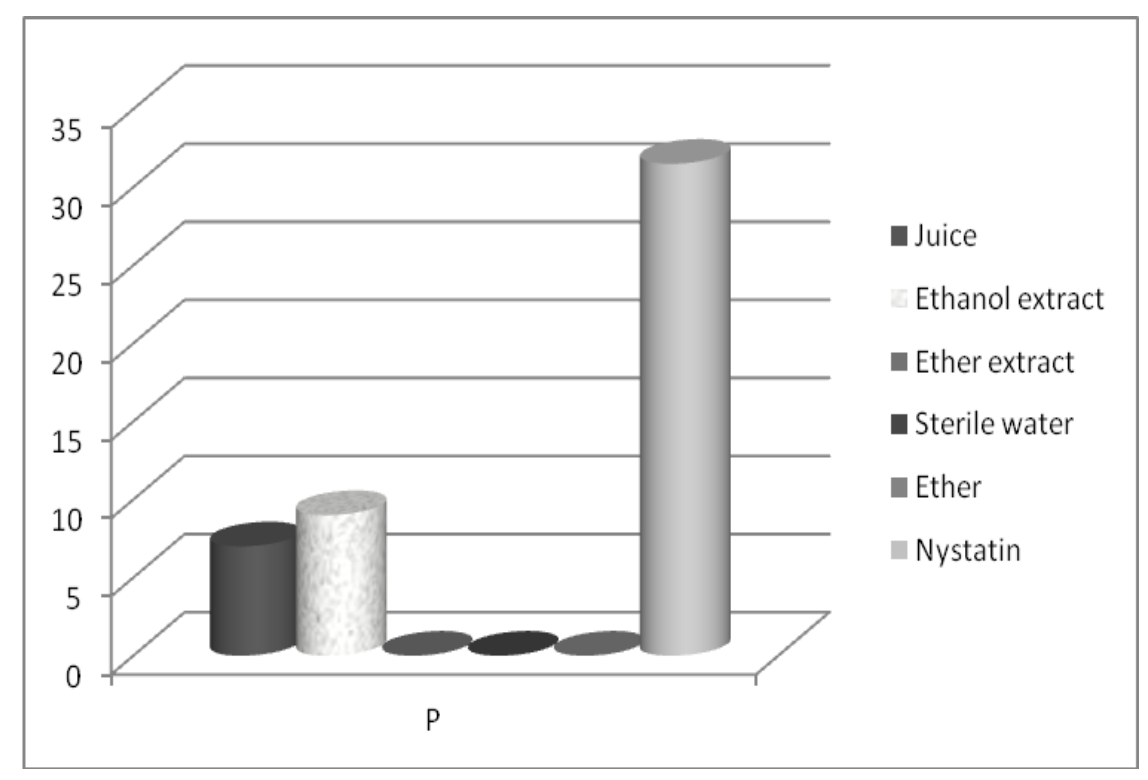

Figure 4. Mean values of inhibition zones' diameters $(\mathrm{mm})$ of the test substances against the alga (P-P. wichermanii)

Difference between juice and ethanol extract's activity against $P$. wichermanii (Fig. 4) was not significant $(p>0.05)$. There was no comparable data in the available literature.

\section{CONCLUSION}

The results of this study indicate the strongest antibacterial effect of raspberry juice followed by ethanol extract, while ether extract of raspberry pomace did not shown antimicrobial activity against any of the tested microorganisms. High volatility of ether make this solvent less suitable for this application and further investigation should be performed with some less volatile solvents, such as methylene chloride or tetrahydrofuran. Although the results of this study are generally similar to previous studies, differences in antimicrobial potential of the tested extracts could possibly be explained by: different chemical composition of raspberry, geographic origin, time of harvest, method of storage and extraction, as well as from differences in the genetic characteristics of the tested strains.

\section{ACKNOWLEDGEMENTS}

This work was supported by the Ministry of Education, Science and Technological Development, Republic of Serbia, Project number 46012 and 41012.

\section{REFERENCES}

1. Anttonen, M., Karjalainen R. (2005). Environmental and genetic variation of phenolic compounds in red raspberry. Journal of Food Composition and Analisys, 18 (8), 759-769.

2. Clinical and Laborathory Standards Institute (CLSI). (2006). Methods for Dilution Antimicrobial Susceptibility Tests for Bacteria that Grow Aerobically. M7-A7 11, Wayne, Pennsylvania.

3. Daniel, E., Krupnick, A., Heur, Y., Blinzler, J., Nims, R., Stoner, G. (1989). Extraction, stability, and quantitation of ellagic acid in various fruits and nuts. Journal of Food Composition and Analisys, 4 (2), 338-349.

4. Hellström, J., Törrönen, R., Mattila, P. (2009). Proanthocyanidins in common food products of plant origin. Journal of Agricultural and Food Chemistry, 57 (17), 7899-7906.

5. Kafkas, E., Ozgen, M., Ozogul, Y., Turemis, N. (2008). Phytochemical and fatty acid profile of selected red raspberry cultivars: a comparative study. Journal of Food Quality, 31 (1), 67-78.

6. Kähkönen, M., Hopia, A., Vuorela, H., Rauha, J., Pihlaja, K., Kujala, T. (1999). Antioxidant Activity of Plant Extracts Containing Phenolic Compounds. Journal of Agricultural Food Chemistry, 47 (10), 3954-3962.

7. Krisch, J., Galgóczy, L., Papp, T., Vagvolgi, C. (2009). Antimicrobial and antioxidant potential of waste products remaining after juice pressing. Annals of the Faculty of Engineering Hunedoara-Journal of engineering, 8 (4), 131134.

8. Krisch, J., Galgóczy, L., Tölgyesi, M., Papp, T., Vágvölgyi, C. (2008). Effect of fruit juices and pomace extracts on the growth of Gram-positive and Gram-negative bacteria. Acta Biologica Szegediensis, 52 (2), 267-270. 
9. Mullen, W., Lean, M., Crozier, A. (2002). Rapid characterization of anthocyanins in red raspberry fruit by high-performance liquid chromatography coupled to single quadrupole mass spectrometry. Journal of Chromatography $A$, 966 (1-2), 63-70.

10. Puupponen-Pimia, R., Nohynek, L., HartmannSchimidlin, S., Kahkonen, M., Heinonen, M., Maatta-Riihinen, K. (2005). Berry phenolics selectively inhibit the growth of intestinal pathogens. Journal of Applied Microbiology, 98, 9911000.

11. Riaz, M., Ahmad, M., Rahman, N. (2011). Antimicrobial screening of fruit, leaves, root and stem of Rubus fruticosus. Journal of Medicinal Plant Research, 24 (5), 5920-5924.
12. Tucakov, J. (1998). Lečenje biljem, Rad, Beograd.

13. Velićanski, A., Cvetković, D., Markov, S (2012). Screening of antibacterial activity of raspberry (Rubus ideaus L.) fruit and pomace extracts. Acta Periodica Techologica, 342 (43), 305313.

14. Velhner, M., Suvajdžić, Lj., Petrović, J., Šeperanda, M. (2012). Antimicrobial resistance of Escherichia coli in wild animals. Arhiv Veterinarske Medicine, 5 (2), 35-44.

15. Zhang, L., Li J., Hogan, S., Chung, H., Welbaum, G., Zhou, K. (2002). Inhibitory effect of raspberries on starch digestive enzyme and their antioxidant properties and phenolic composition. Food Chemistry, 119 (2), 592-599.

\section{РАЗЛИЧИТ АНТИМИКРОБНИ ЕФЕКАТ МАЛИНЕ У ЗАВИСНОСТИ ОД НАЧИНА ИЗДВАЈАҢА АКТИВНИХ КОМПОНЕНАТА}

Тамара П. Крстић ${ }^{1}$, Љиљана Ђ. Сувајџић ${ }^{2}$, Срђан 3. Стојановић ${ }^{1}$, Маја Ј. Велхнер ${ }^{3}$, Дубравка С. Миланов ${ }^{3}$, Гордана М. Бојић ${ }^{4}$, Небојша М. Илић ${ }^{5}$

${ }^{1}$ Европски универзитет Фармацеутски факултет, Трг младенаца 5, Нови Сад, Србија ${ }^{2}$ Медицински фракултет Нови Сад, Департман за фармацију, Хајдук Вељкова 1, Нови Сад, Србија

${ }^{3}$ Научни институт за ветеринарство “Нови Сад”, Руменачки пут 20, Нови Сад, Србија ${ }^{4}$ Институт за јавно здравље Војводине, Футошка 121, Нови Сад, Србија ${ }^{5}$ Универзитет у Новом Саду, Научни институт за прехрамбене технологије, Булевар цара Лазара 1, Нови Сад, Србија

Сажетак: Плодови малине, захваљујући свом разноврсном хемијском саставу, испољавају бројна дејства корисна за ветеринарску и хуману медицину. Једно од тих дејстава је антимикробна активност. Правилна обрада биљног материјала је најважнији поступак при сваком испитивању његових активности. Обрада материјала условљава издвајање хемијских материја у испитиваном узорку, тако да различити поступци могу да доведу до издвајања различитих активних принципа.

Сок малине је добијен цеђењем плодова малине и филтрацијом. Остаци плодова малине после цеђења (комина) су екстраховани етанолом и етром. Циљ рада је био да се утврди најповољнији начин екстракције малине ради добијања екстракта са најјачим антимикробним својставима. Цеђење плодова и етанолна екстракција комине малине су показале супериорност над етарском екстракцијом применом бунарчић дифузионе методе испитивања.

Кључне речи: малина, антимикробик, издвајање активних принципа, сок, етанол, 